\title{
Analysis of progression-free survival of first-line tyrosine kinase inhibitors in patients with non-small cell lung cancer harboring leu858Arg or exon 19 deletions
}

\author{
Feng-Che Kuan ${ }^{1,2}$, Shih-Hong $\mathbf{L i}^{3}$, Chih-Liang Wang ${ }^{3,4}$, Meng-Hung Lin ${ }^{5}$, Ying-Huang \\ Tsai ${ }^{6,7}$, Cheng-Ta Yang ${ }^{3,7}$ \\ ${ }^{1}$ Department of Hematology and Oncology, Department of Medicine, Chang-Gung Memorial Hospital, Chiayi 61363, Taiwan \\ ${ }^{2}$ Graduate Institute of Clinical Medical Sciences, Chang-Gung University, Taoyuan 33302, Taiwan \\ ${ }^{3}$ Department of Thoracic Medicine, Chang-Gung Memorial Hospital, Taoyuan 33305, Taiwan \\ ${ }^{4}$ Department of Medicine, Chang-Gung University, Taoyuan 33302, Taiwan \\ ${ }^{5}$ Cencer of Excellence for Chang Gung Research Datalink, Chang-Gung Memorial Hospital, Chiayi 61363, Taiwan \\ ${ }^{6}$ Division of Respiratory and Critical Care Medicine, Department of Medicine, Chang-Gung Memorial Hospital, Chiayi 61363, Taiwan \\ ${ }^{7}$ Department of Respiratory Therapy, Chang-Gung University, Taoyuan 33302, Taiwan \\ Correspondence to: Cheng-Ta Yang, email: yang1946@cgmh.org.tw
}

Keywords: gefitinib, erlotinib, afatinib, Leu858Arg, Thr790Met

Received: August 15, $2016 \quad$ Accepted: November 14, 2016

Published: December 07, 2016

\section{ABSTRACT}

Background: Gefitinib, erlotinib and afatinib provide remarkable response rates and progression-free survival compared to platinum-based chemotherapy in patients with non-small cell lung cancer harboring epidermal growth factor receptor-activating mutations, and are therefore standard first-line treatment in these patients. However, no study has compared these drugs regarding progression-free survival.

Materials and Methods: We conducted this retrospective study at a single medical center in Taiwan from February 16, 2011 to October 30, 2015. We used the KaplanMeier method to estimate survival, and multivariate Cox proportional hazard models to estimate adjusted hazard ratios and $95 \%$ confidence intervals.

Findings: Of the 1006 patients diagnosed with stage IIIb and IV non-small cell lung cancer in the study period, $448(44.5 \%)$ had EGFR-activating mutations and received first-line therapy with gefitinib $(n=304,67.6 \%)$, erlotinib $(n=63,14.3 \%)$, or afatinib $(n=81,18.1 \%)$. The median duration of follow-up for progression-free survival was 12.1 months in the gefitinib arm (Interquartile range [IQR]: 5.5-16.5), 11.2 months in the erlotinib arm (IQR: 4.9-16.7), and 10.3 months in the afatinib arm (IQR: 7.0-14.2). Progression-free survival was significantly longer in the patients who received afatinib or erlotinib compared to those who received gefitinib (log-rank test, $p<0.001$ ), and the median progression-free survival was 11.4 months in the gefitinib group.

Interpretation: Afatinib and erlotinib provide significant benefits in progressionfree survival compared to gefitinib in first-line treatment of patients with non-smallcell lung cancers harboring EGFR-activating mutations. Further clinical trials are warranted to validate these findings.

\section{INTRODUCTION}

Targeting epidermal growth factor receptor (EGFR) and downstream signaling transduction has been shown to be beneficial in the treatment of lung cancer, which accounts for $19.4 \%$ of all cancer-related deaths worldwide
$[1,2]$. Gefitinib (Iressa ${ }^{\circledR}$, marketed by AstraZeneca) is the first tyrosine kinase inhibitor, which acts by binding to the adenosine triphosphate (ATP) binding site of this enzyme $[3,4]$. Erlotinib (Tarceva ${ }^{\circledR}$, marketed by Roche), another first-generation EGFR tyrosine kinase inhibitor, also inhibits the formation of phosphotyrosine residues 
and initiation of subsequent signal cascades [5]. Afatinib (Giotrif $^{\mathbb{B}}$, marketed by Boehringer Ingelheim), a secondgeneration EGFR tyrosine kinase inhibitor, unlike gefitinib and erlotinib, provides irreversible inhibition of ATP binding by forming permanent covalent bonds, and it has been shown to be active in preclinical study against mutations such as Thr790Met [6], which have been shown to contribute to primary and acquired resistance to reversible tyrosine kinase inhibitors [7-9]. De novo Thr790Met is more likely to coexist with Leu858Arg than with exon 19 deletions, and these two mutations account for around $90 \%$ of EGFR-activating mutations $[10,11]$. All of these tyrosine kinase inhibitors have shown remarkable response rates and benefits in progression-free survival compared to first-line conventional platinumbased chemotherapy [12-21], and thus they have become the standard treatment for patients with metastatic nonsmall-cell lung cancer harboring EGFR-activating mutations [22].

A recent phase III randomized controlled trial, LUX-Lung 7, reported that afatinib had significant benefits in progression-free survival (HR, 0.73; 95\% CI, $0.57-0.95 ; p=0.017$ ) compared to gefitinib in patients with EGFR-mutated metastatic non-small-cell lung cancer [23]. In addition, the ARCHER 1050 (ClinicalTrials. gov Identifier NCT01774721) trial comparing another irreversible tyrosine kinase inhibitor, dacomitinib to gefitinib is currently ongoing. However, phase III randomized controlled trials mainly enroll patients with a good performance, and no trial has compared these three tyrosine kinase inhibitors together. Tyrosine kinase inhibitors have been shown to provide dramatic benefits in response rates, and provide benefits to patients presenting with visceral crisis and impaired performance status in real world practice. Therefore, we conducted this retrospective study to elucidate the efficacy of these three tyrosine kinase inhibitors as first-line treatment in patients with EGFR-mutated non-small cell lung cancer.

\section{RESULTS}

Between February 16, 2011 and October 30, 2015, 1006 patients were screened, 448 (44.5\%) of whom had newly diagnosed or recurrent stage IIIb/IV lung adenocarcinoma and received first-line gefitinib $(n=304)$, erlotinib $(n=63)$, or afatinib $(n=81)$ (Figure 1$)$. Baseline demographics were similar between the treatment groups, except for a slight imbalance in sex $(p=0.213)$ and performance status $(>1,24 \%$ in the gefitinib arm, $p=0.017$, Table 1). The composite of exon 19 deletions or Leu858Arg in each arm was not statistically significant $(p=0.119)$, albeit a slightly higher percentage of exon 19 deletions $(59.3 \%)$ in the afatinib group. The frequency of compound mutations were listed in Supplementary Table S2. The median outpatient dosages of gefitinib, erlotinib and afatinib were $248 \mathrm{mg} /$ day (IQR, 238-250),
$149 \mathrm{mg} /$ day (IQR, 140-150), and $39 \mathrm{mg} /$ day (IQR, 32-40), respectively. The median durations of followup for progression-free survival were 12.1 months in the gefitinib arm (IQR 5.5-16.5), 11.2 months in the erlotinib arm (IQR 4.9-16.7), and 10.3 months in the afatinib arm (IQR 7.0-14.2). After 18 months of progressionfree survival, $63(20.7 \%)$ patients were still receiving treatment in the gefitinib arm, compared to $12(19.0 \%)$ patients in the erlotinib arm and six (7.4\%) in the afatinib arm. Progression-free survival was significantly longer in the patients who received afatinib or erlotinib compared to those who received gefitinib (log-rank test, $p=0.0001$, Figure 2). The median progression-free survival was not reached in the afatinib and erlotinib groups, and 11.4 months in the gefitinib group (afatinib versus gefitinib, $p<0.001$ and erlotinib versus gefitinib $p=0.005$, respectively, Figure $3 \mathrm{~A}$ and $3 \mathrm{~B}$ ).

Multivariate stratified analysis of progression-free survival is shown in Figure 4 and Supplementary Table S3 and S4. After adjusting for covariates including age, sex, smoking, EGFR mutation, baseline brain metastasis and performance status, afatinib reduced the risk of progression in all subgroups except for performance status > $1(\mathrm{HR}, 0.78 ; 95 \% \mathrm{CI}, 0.31-1.97)$ and a trend of a reduction in risk in patients with synchronous brain metastasis (HR, 0.42; 95\% CI, 0.16-1.05) compared to the gefitinib group. After adjusting for these covariates, erlotinib reduced the risk of progression in the patients with exon 19 deletions (HR, 0.34; 95\% CI, 0.16-0.70), without synchronous brain metastasis (HR, 0.56; 95\% CI, $0.34-0.92$ ), with a performance status of 0 and 1 (HR, 0.53 ; 95\% CI, 0.33-0.86), and in never smokers (HR, 0.52; 95\% CI, 0.31-0.90). Analysis of progression-free survival according to the type of mutation (exon 19 deletions or Leu858Arg) is shown in Figure 5A and 5B. In the patients with exon 19 deletions, afatinib or erlotinib treatment was associated with significantly longer progressionfree survival than gefitinib $(p=0.001)$. However, in the patients with the Leu858Arg mutation, afatinib was associated with significantly longer progression-free survival compared to erlotinib or gefitinib $(p=0.02)$.

\section{DISCUSSION}

The recent LUX-Lung 7 trial reported statistically significant benefits in progression-free survival in patients receiving afatinib compared to gefitinib as first-line treatment in patients with non-small cell lung cancer harboring EGFR-activating mutations (HR, 0.73; 95\% CI, 0.57-0.95, $p=0.017$ ) [23]. Erlotinib, another firstgeneration tyrosine kinase inhibitor, is not included in this head-to-head trial, although previous studies have indicated a similar efficacy with gefitinib [24-26]. To the best of our knowledge, the current study is the first to investigate differences in progression-free survival between these three EGFR tyrosine kinase inhibitors. Our 
Table 1: Baseline Characteristics for NSCLC by EGFR-TKIs

\begin{tabular}{|c|c|c|c|c|c|c|c|}
\hline & \multicolumn{6}{|c|}{ EGFR-TKIs } & \multirow[b]{3}{*}{$P$-value } \\
\hline & \multicolumn{2}{|c|}{ Gefitinib } & \multicolumn{2}{|c|}{ Erlotinib } & \multicolumn{2}{|c|}{ Afatinib } & \\
\hline & $\mathbf{n}$ & $(\%)$ & $\mathbf{n}$ & $(\%)$ & $\mathrm{n}$ & $(\%)$ & \\
\hline Total & 304 & & 63 & & 81 & & \\
\hline Sex & & & & & & & 0.213 \\
\hline Men & 114 & $(37.5)$ & 24 & $(38.1)$ & 39 & $(48.1)$ & \\
\hline Women & 190 & $(62.5)$ & 39 & $(61.9)$ & 42 & (51.9) & \\
\hline Age (years) & & & & & & & 0.095 \\
\hline$<65$ & 154 & $(50.7)$ & 34 & $(54.0)$ & 52 & (64.2) & \\
\hline$\geq 65$ & 150 & $(49.3)$ & 29 & $(46.0)$ & 29 & $(35.8)$ & \\
\hline Mean (range) & 65 & $(33-93)$ & 67 & $(47-90)$ & 64 & $(37-83)$ & 0.191 \\
\hline Smoking & & & & & & & 0.802 \\
\hline Never & 226 & $(74.3)$ & 48 & $(76.2)$ & 63 & (77.8) & \\
\hline Current or ever & 78 & $(25.7)$ & 15 & $(23.8)$ & 18 & $(22.2)$ & \\
\hline Clinical stage & & & & & & & 0.449 \\
\hline IIIb & 16 & (5.3) & 5 & (7.9) & 7 & (8.6) & \\
\hline IV & 288 & (94.7) & 58 & $(92.1)$ & 74 & (91.4) & \\
\hline EGFR mutation & & & & & & & 0.119 \\
\hline Del19 & 148 & $(48.7)$ & 27 & $(42.9)$ & 48 & $(59.3)$ & \\
\hline L858R & 156 & $(51.3)$ & 36 & $(57.1)$ & 33 & $(40.7)$ & \\
\hline Baseline brain metastases & & & & & & & 0.867 \\
\hline Absence & 244 & $(80.3)$ & 52 & $(82.5)$ & 64 & $(79.0)$ & \\
\hline Presence & 60 & $(19.7)$ & 11 & $(17.5)$ & 17 & $(21.0)$ & \\
\hline ECOG PS & & & & & & & 0.017 \\
\hline $0 \& 1$ & 231 & $(76.0)$ & 56 & $(88.9)$ & 70 & $(86.4)$ & \\
\hline$>1$ & 73 & $(24.0)$ & 7 & $(11.1)$ & 11 & $(13.6)$ & \\
\hline Grade & & & & & & & 0.139 \\
\hline 1 & 59 & (19.4) & 12 & $(19.4)$ & 25 & $(30.9)$ & \\
\hline 2 & 64 & $(21.1)$ & 19 & $(30.2)$ & 21 & $(25.9)$ & \\
\hline 3 & 49 & $(16.1)$ & 9 & $(14.3)$ & 9 & (11.1) & \\
\hline missing & 132 & (43.4) & 23 & $(36.5)$ & 26 & (32.1) & \\
\hline
\end{tabular}

Abbreviations: ECOG PS, Eastern Cooperative Oncology Group performance status.

findings may provide important information for physicians when choosing the first-line treatment for these patients. Consistent with the results of the LUX-Lung 7 trial, afatinib was superior to gefitinib in our study $(p<0.001)$. In addition, erlotinib was superior to gefitinib ( $p=0.005$ ). In the multivariable comparisons of afatinib and gefitinib, the benefits in progression-free survival were statistically significant and consistent in different subgroup analyses after adjusting for other covariates (HR, $0.51 ; 95 \%$ CI, 0.34-0.78), except for patients with baseline brain metastasis (absence vs. presence) and worse performance status ( 0 and 1 vs. $>1)$ indicating the superiority of afatinib, consistent with the findings of the LUX-Lung 7 trial.
Similarly, erlotinib outperformed gefitinib but to a lesser extent (HR, 0.57; 95\% CI, 0.37-0.89) in multivariable analysis. With regards to the type of mutation and progression-free survival, afatinib and erlotinib performed better than gefitinib in the patients with exon 19 deletion mutations $(p=0.001)$, and afatinib performed better than erlotinib and gefitinib in the patients with Leu858Arg mutations $(p=0.02)$. This may be because afatinib has a broader inhibitory profile, which can delay resistance mechanisms in both exon 19 deletion and Leu858Arg mutations [6, 27-31]. De novo Thr790Met mutations may also account for this poor response to reversible tyrosine kinase inhibitors [7-9, 32]. However, the incidence of de novo Thr790Met has been reported 


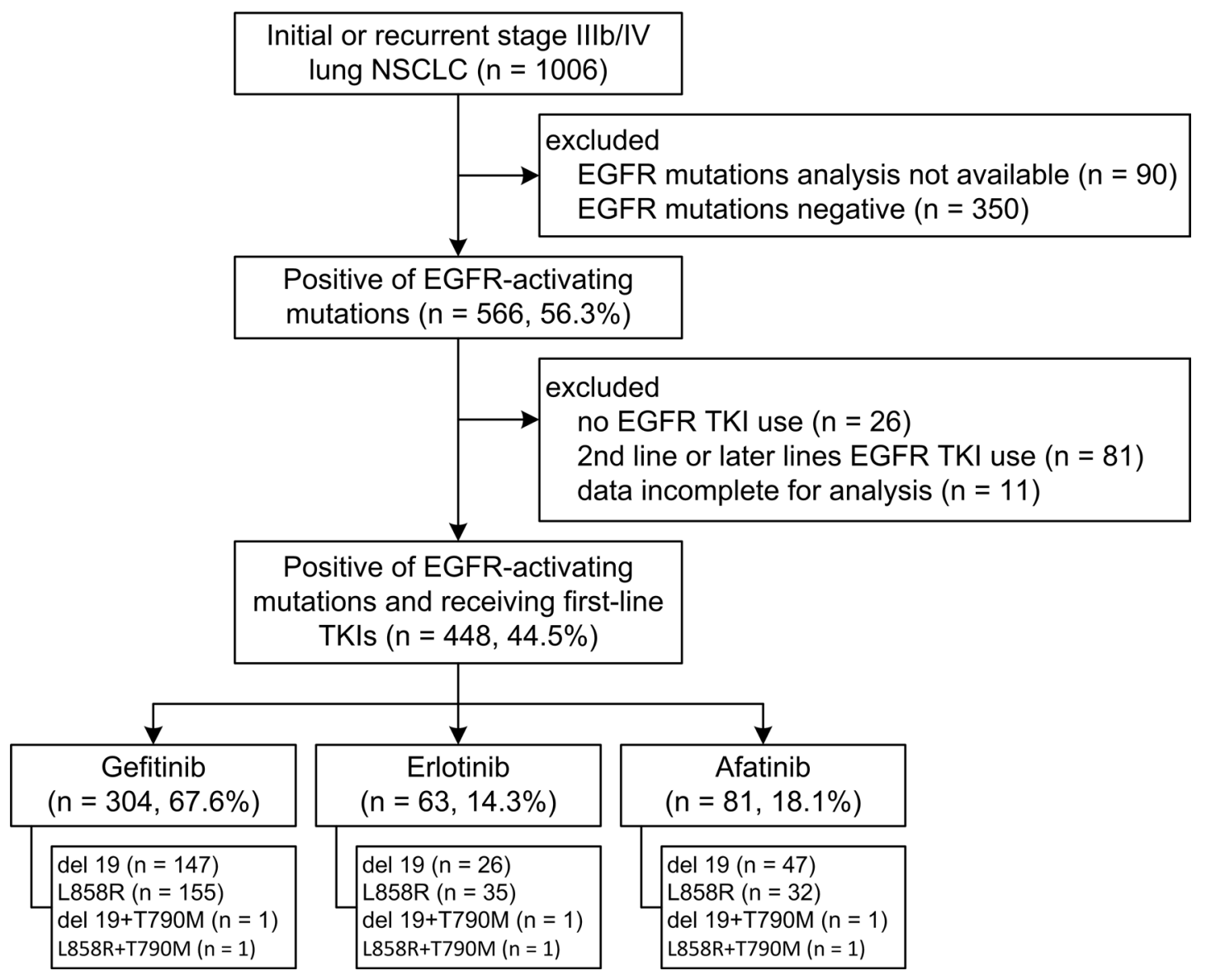

Figure 1: Patient disposition.

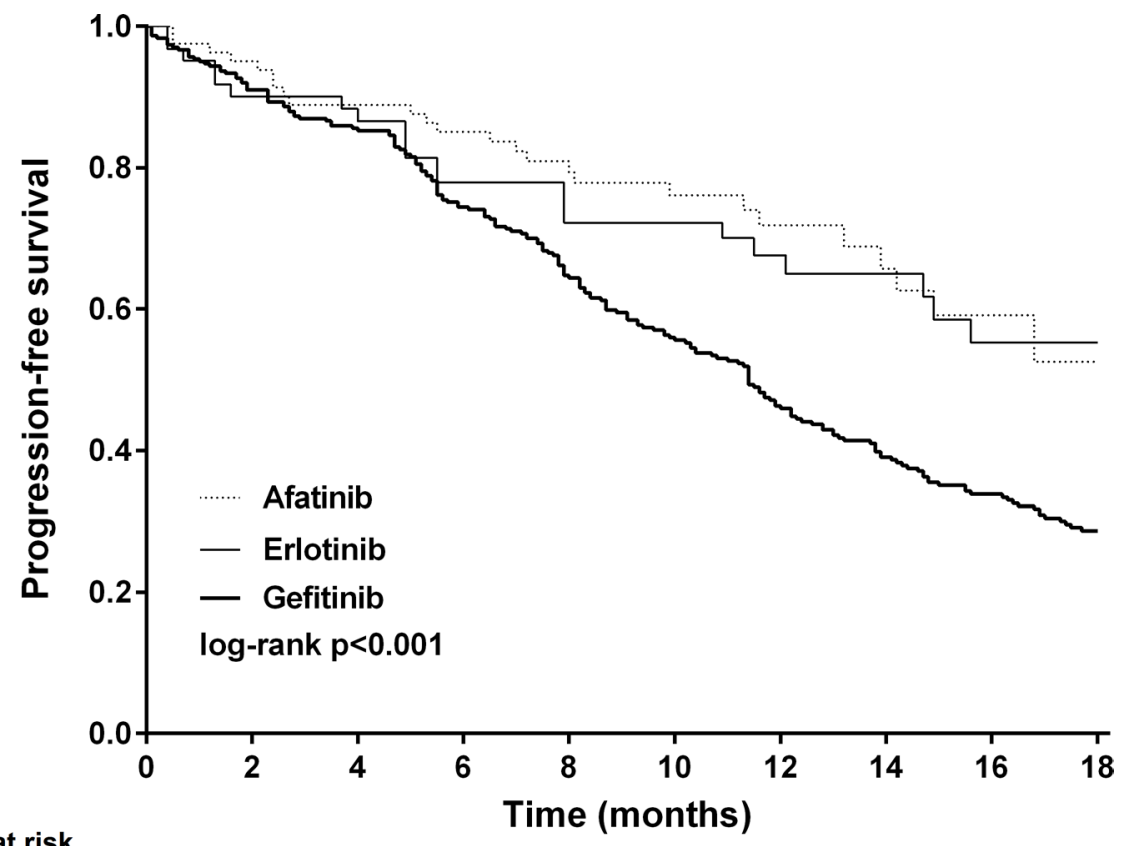

No. at risk

$\begin{array}{rrrrrrrrrrr}\text { Afatinib } & 81 & 77 & 71 & 65 & 53 & 43 & 30 & 21 & 11 & 6 \\ \text { Erlotinib } & 63 & 53 & 51 & 44 & 36 & 33 & 27 & 22 & 17 & 12 \\ \text { Gefitinib } & 304 & 270 & 253 & 219 & 185 & 155 & 123 & 99 & 82 & 63\end{array}$

Figure 2: Kaplan-Meier survival curves of progression-free survival in patients received gefitinib, erlotinib and afatinib. 
to range from $0 \%$ to $78.9 \%$ depending on the molecular testing technique [10, 32-39]. Although the relationship between baseline Thr790Met and exon 19 deletion or Leu858Arg has yet to be elucidated, a higher baseline incidence of Thr790Met mutations has been associated with the Leu858Arg (Table 2). In this study, the baseline incidence of Thr790Met in the patients with Leu858Arg $(7 / 260=2.7 \%)$ was higher than that in the patients with exon 19 deletions $(4 / 257=1.5 \%)$. Previous literatures showed only modest activity of second-generation TKIs against Thr790Met in TKI-pretreated or -naïve patients [29, 40, 41]. Nevertheless, in the LUX-Lung 7 trial, afatinib was shown to have a favorable response and to be able to overcome primary resistance in those with Leu858Arg compared to gefitinib. Other head-to-

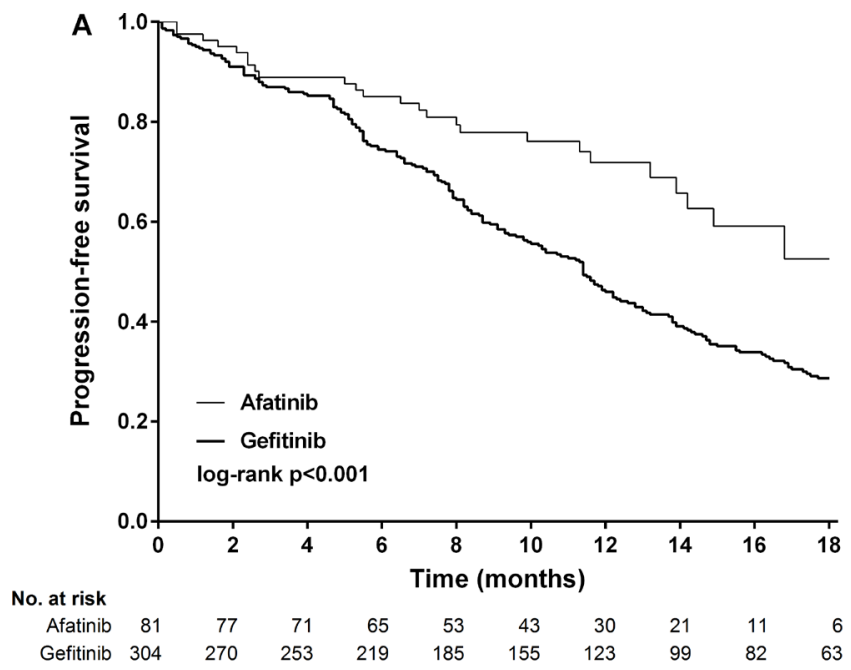

head studies such as ARCHER1050 (ClinicalTrials.gov identifier: NCT01774721) and FLAURA (ClinicalTrials. gov identifier: NCT02296125) trials are currently ongoing, and should provide more insight into these issues.

There are several limitations to this study. First, the median follow-up time was less than 1 year in the erlotinib and afatinib arms, and neither arm reached their median progression-free survival. However, the median followup time in the gefitinib arm was 12.1 months, which may serve as a good reference compared with previous studies [12-15, 33, 37, 42-44], and 79.3\% of these patients had clinical progression or death then. The differences between erlotinib and afatinib compared to gefitinib were evident, although they may be relatively modest with longer follow-up. Nevertheless, this is unlikely to substantively

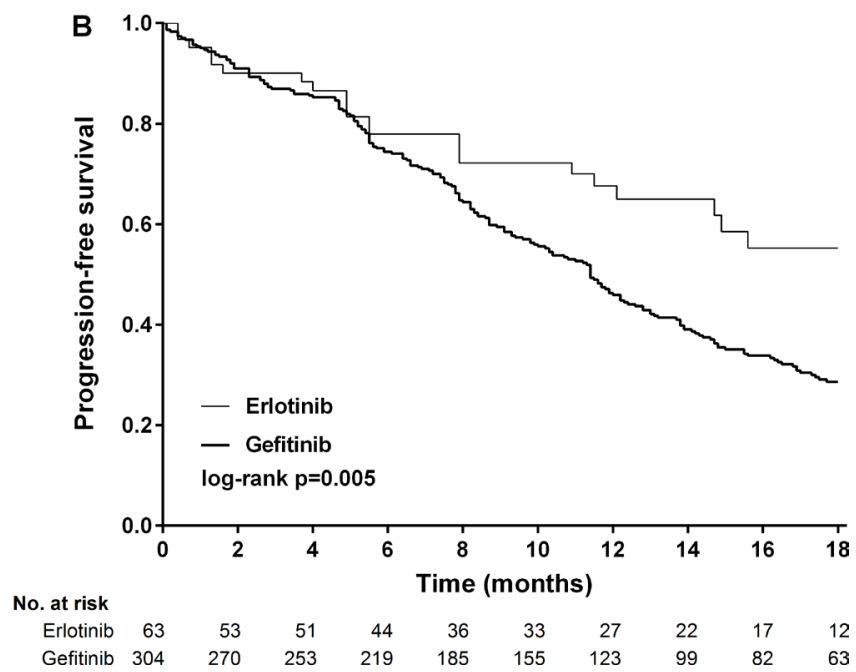

Figure 3: Kaplan-Meier survival curves of progression-free survival in patients received (A) afatinib and gefitinib and (B) erlotinib and gefitinib.

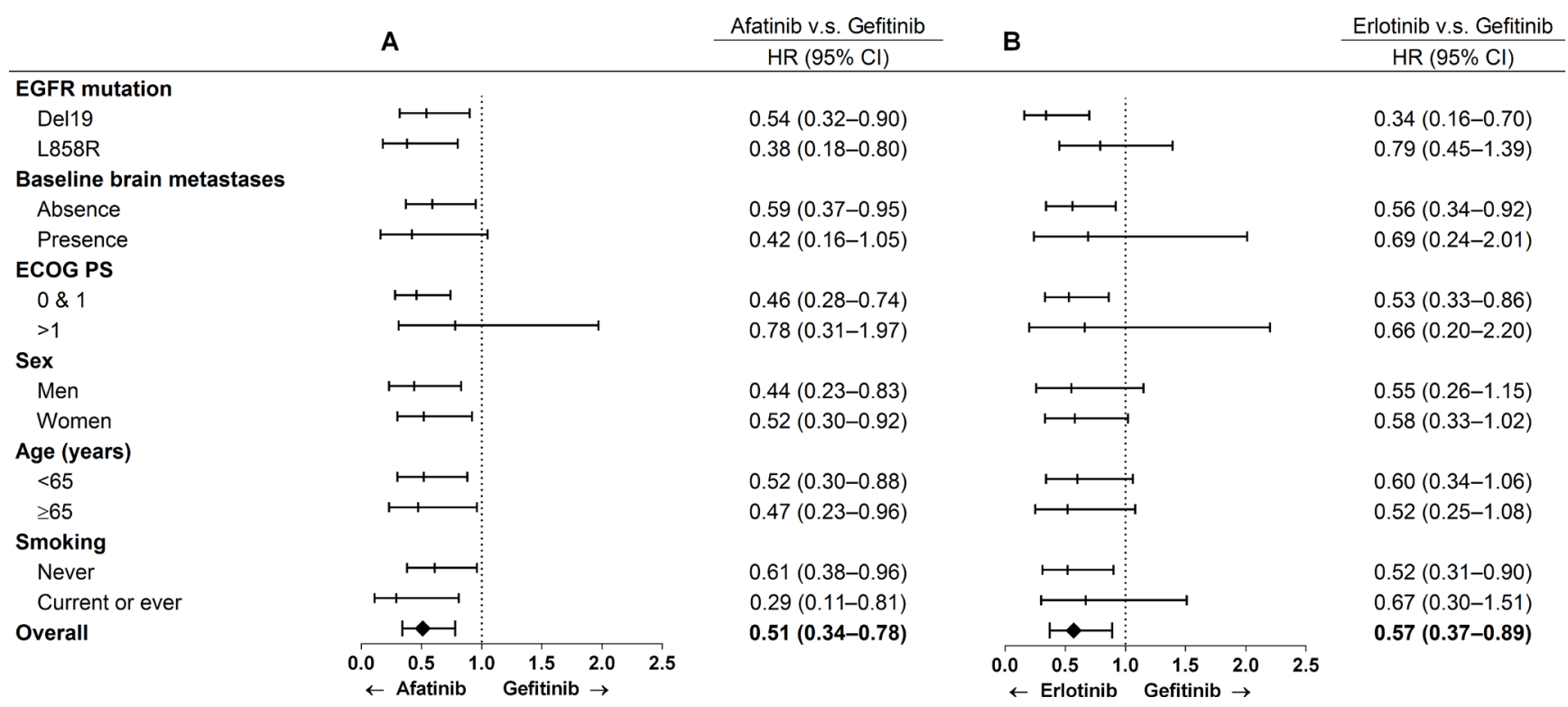

Figure 4: Multivariable analysis of progression-free survival in patients received afatinib v.s. gefitinib and erlotinib v.s. gefitinib 
Table 2: Literatures regarding baseline Thr790Met in EGFR-activating mutations

\begin{tabular}{|c|c|c|c|}
\hline Author & T790M+del19/del 19 & T790M+L858R/L858R & Country \\
\hline Fujita $2012^{10}$ & $16 / 22(72.7 \%)$ & $12 / 13(92.3 \%)$ & Japan \\
\hline Yu $2014^{32}$ & $4 / 20(20.0 \%)$ & $16 / 20(80.0 \%)$ & USA \\
\hline Costa $2014^{10}$ & $50 / 84(59.5 \%)$ & $29 / 39(74.4 \%)$ & Spain \\
\hline Rosell $2011^{10}$ & $42 / 78(53.8 \%)$ & $36 / 53(67.9 \%)$ & USA \\
\hline Li $2014^{36}$ & $5 / 28(17.9 \%)$ & $10 / 26(38.5 \%)$ & China \\
\hline Stahel $2015^{38}$ & $23 / 70(32.8 \%)$ & $14 / 39(35.9 \%)$ & Spain \\
\hline $\mathrm{Su} 2012^{10}$ & $4 / 28(14.3 \%)$ & $24 / 67(35.8 \%)$ & Taiwan \\
\hline Maheswaran $2008^{10}$ & $5 / 16(31.3 \%)$ & $2 / 7(28.5 \%)$ & USA \\
\hline Lee $2015^{10}$ & $11 / 76(14.5 \%)$ & $13 / 48(27.1 \%)$ & South Korea \\
\hline Hashida $2014^{10}$ & $5 / 26(19.2 \%)$ & $6 / 28(21.4 \%)$ & Japan \\
\hline Sequist $2008^{40}$ & $0 / 18(0 \%)$ & $2 / 11(18.2 \%)$ & USA \\
\hline Ren $2012{ }^{10}$ & $1 / 26(3.8 \%)$ & $5 / 42(11.9 \%)$ & China \\
\hline Janne $2014^{10}$ & $1 / 26(3.8 \%)$ & $2 / 23(8.7 \%)$ & $\begin{array}{l}\text { Hong Kong, Japan, South Korea, } \\
\text { Taiwan, USA }\end{array}$ \\
\hline Arrieta $2015^{10}$ & $3 / 110(2.7 \%)$ & $4 / 50(8.0 \%)$ & Mexico \\
\hline Ragazzi $2015^{10}$ & $3 / 38(7.9 \%)$ & $1 / 47(2.1 \%)$ & Italy \\
\hline Inukai $2006^{10}$ & $1 / 44(2.3 \%)$ & $3 / 43(7.0 \%)$ & Japan \\
\hline He $2013^{10}$ & $7 / 108(6.5 \%)$ & $4 / 104(3.8 \%)$ & China \\
\hline Kris $2013^{35}$ & $3 / 106(2.8 \%)$ & $4 / 68(5.9 \%)$ & USA \\
\hline Yang $2013^{10}$ & $3 / 237(1.3 \%)$ & $6 / 183(3.3 \%)$ & $\begin{array}{l}\text { Asia, Europe, North/South America, } \\
\text { Australia, China, Thailand, South Korea }\end{array}$ \\
\hline Fukuoka $2011^{10}$ & $4 / 136(2.9 \%)$ & $3 / 107(2.8 \%)$ & East Asia \\
\hline Guo $2015^{10}$ & $1 / 104(0.9 \%)$ & $2 / 73(2.7 \%)$ & China \\
\hline Keam $2014^{10}$ & $3 / 180(1.7 \%)$ & $2 / 109(1.8 \%)$ & South Korea \\
\hline Inoue $2016^{33}$ & $4 / 823(0.5 \%)$ & $5 / 681(0.7 \%)$ & Japan \\
\hline Baek $2015^{10}$ & $1 / 287(0.3 \%)$ & $1 / 206(0.5 \%)$ & South Korea \\
\hline Wu $2011^{39}$ & $0 / 258(0 \%)$ & $0 / 260(0 \%)$ & Taiwan \\
\hline
\end{tabular}
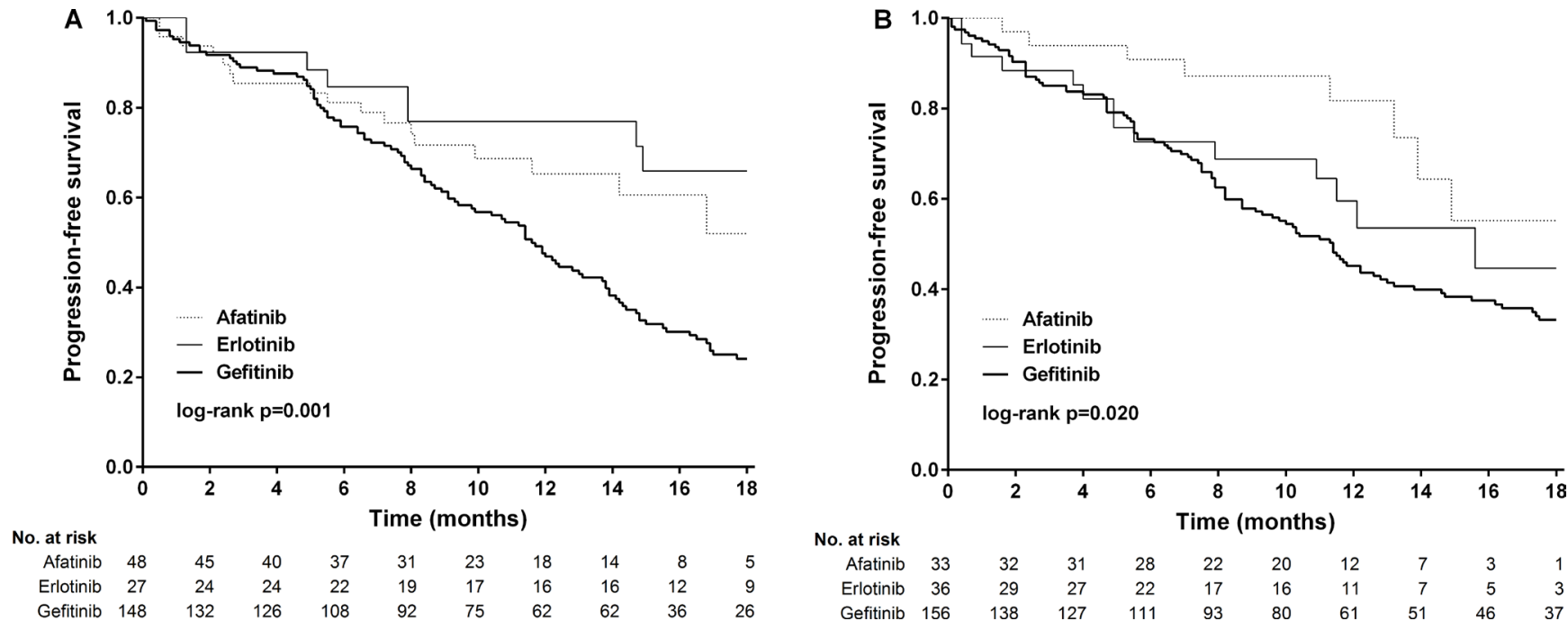

Figure 5: Kaplan-Meier survival curves of progression-free survival of patients received gefitinib, erlotinib and afatinib in (A) exon 19 deletions and (B) Leu858Arg 
change our results. Second, the number of cases differed in the three arms, and more patients received gefitinib than erlotinib or afatinib. However, there were no significant differences in demographic data except for more patients with a poor performance status in the gefitinib group. In addition, some clinical factors such as pleural effusion were not documented, which may have been a source of confounding. On the other hand, baseline brain metastasis and smoking status were relatively consistent in all treatment arms. These factors have been reported to be prognostic factors in these patients, and thus we adjusted for other covariates to make appropriate comparisons $[44,45]$. Third, the BCL2-Like 11 (BIM) deletion polymorphism has been reported to occur in $12.8 \%$ to $18.6 \%$ of Asians, and to be associated with an inferior response to tyrosine kinase inhibitors [46-48]. Although Lee et al. reported no predictive role of BIM regarding the outcomes of tyrosine kinase inhibitor therapy [49], we did not check this in our study population. Finally, we did not report the side effects in the treatment groups. It is known that afatinib is associated with a higher frequency of diarrhea and rash, and that gefitinib is associated with a higher frequency of liver function abnormalities and interstitial pneumonitis [23, 50]. Our results of progression-free survival are based on real world practice with acceptable dosages of medication.

\section{MATERIALS AND METHODS}

\section{Study design and participants}

This study was conducted at Linkou Chang-Gung Memorial Hospital (LK-CGMH), a university-affiliated medical center with more than 8,00 newly-documented cases of lung cancer a year. In Taiwan, gefitinib has been reimbursed by the National Health Insurance program (NHIP) for the first-line treatment of patients with stage IIIb or IV non-small cell lung cancer with EGFR-activating mutations since June 2011, with erlotinib and afatinib being added in November 2013 and May 2014, respectively. Patients were included into this study if they had: (1) initial or recurrent stage IIIb or IV lung adenocarcinoma that had been diagnosed at LK-CGMH between February 16, 2011 and October 30, 2015; (2) activating somatic EGFR mutations; and (3) treatment with first-line gefitinib, erlotinib, or afatinib. The Institutional Research Ethics Committee of CGMH approved this study.

\section{Procedures}

Lung cancer was pathologically confirmed by a bronchoscopic or CT-guided biopsy, pleural effusion cytology and/or surgical procedures. EGFR mutation analysis was performed in patients with adenocarcinoma, large cell carcinoma, or carcinoma with an adenocarcinoma component such as adenosquamous carcinoma. The mutation analysis was performed by direct sequencing with polymerase chian reaction or with SCORPION technology in combination with an Amplified Refractory Mutation System (ARMS, QIAGEN, Hilden, Germany) or competitive allele-specific TaqMan PCR (Cast-PCR, Applied Biosystems, Foster City, CA) with genomic DNA from paraffin-embedded tissue (Supplement Table S1). [51, 52].

Patients in the gefitinib group received $250 \mathrm{mg}$ orally once daily, with a reduction in the dose being permitted on an individual basis. The patients in the erlotinib group received $150 \mathrm{mg}$ orally once daily, and the dose could be reduced to $100 \mathrm{mg}$ if there were intolerable side effects. Similarly, the patients in the afatinib group received $40 \mathrm{mg}$ orally once daily, with a reduction to $30 \mathrm{mg}$ being permitted if necessary. Chest computed tomography or other clinical imaging modalities (chest radiography, brain magnetic resonance imaging, bone scan, or positron emission tomography-computed tomography) were arranged every 3 months to re-evaluate the disease status, and if the disease was considered to be under control (either a complete response, partial response or stable disease according to RECIST 1.1) [53], the individual TKI would be prescribed and reimbursed again by NHIP after re-application.

\section{Outcomes and statistical analysis}

Progression-free survival was calculated from the time of initiating tyrosine kinase inhibitor treatment to the time of clinical progression or death, whichever occurred first. The time of "clinical progression" was defined as the date that radiographic imaging was judged by both the physician and radiologist to be clinically significant, and warranting a change in therapy. Kaplan-Meier curves were used to estimate survival, and the log-rank test was used to compare times to events between groups. Multiple analyses and stratified analyses were performed using Cox proportional hazards regression models (hazard ratio, HR). All reported $p$ values were two-sided, and adjustments were made for multiple comparisons. All analyses were performed using SAS version 9.4 (SAS Inc., Cary, NC).

\section{Role of the funding source}

The authors declare no conflicts of interest and no funding source.

\section{CONCLUSIONS}

Afatinib and erlotinib had a significantly longer progression-free survival than gefitinib in the first-line treatment of patients with lung adenocarcinoma harboring common EGFR-activating mutations. The patients with 
Leu858Arg mutations who received afatinib had a longer progression-free survival than those receiving gefitinib or erlotinib, which may have been due to a higher baseline incidence of Thr790Met. Further clinical trials are warranted to validate these findings.

\section{ACKNOWLEDGMENTS}

This study was supported by Chang Gung Research Project grant (CMRPG3D0291) to C.T. Yang. We wish to express our sincere gratitude to Shao-Hsuan Lin, KaiYu Hsieh, and Jrhau Lung for providing help during the period of this study. We would also like to thank the Center of Excellence for Chang Gung Research Datalink (CORPG6D0161-2, CORPG6D0191, CORPG6D0251-2) for assistance in data analysis. Finally, we thank the members of the Cancer Center, Chang Gung Memorial Hospital for their invaluable help.

\section{CONFLICTS OF INTEREST}

The authors declare no conflicts of interest, such as employment, consultancies, stock ownership, honoraria, paid expert testimony, and travel grants that may be perceived as prejudicing the impartiality of the research.

\section{FUNDING}

No funding was provided for this study.

\section{Authors' contributions}

Feng-Che Kuan was responsible for the study concept and design and drafting of the manuscript. ShihHong Li and Meng-Hung Lin participated in acquisition, analysis, and interpretation of data. Chih-Liang Wang and Ying-Huang Tsai provided technical and material support. Cheng-Ta Yang was in charge of the study concept and design, supervised the study and critically revised the manuscript for important intellectual content.

\section{REFERENCES}

1. International Agency for Research on Cancer. GLOBOCAN 2012: Country Fast Stat. 2014. http://globocan.iarc.fr/Pages/ fact_sheets_cancer.aspx (accessed July 8, 2016).

2. Russo A, Franchina T, Ricciardi GR, Picone A, Ferraro G, Zanghi M, Toscano G, Giordano A, Adamo V. A decade of EGFR inhibition in EGFR-mutated non small cell lung cancer (NSCLC): Old successes and future perspectives. Oncotarget. 2015; 6:26814-26825. doi: 10.18632/ oncotarget.4254.

3. Lynch TJ, Bell DW, Sordella R, Gurubhagavatula S, Okimoto RA, Brannigan BW, Harris PL, Haserlat SM, Supko JG, Haluska FG, Louis DN, Christiani DC, Settleman J, et al. Activating mutations in the epidermal growth factor receptor underlying responsiveness of nonsmall-cell lung cancer to gefitinib. N Engl J Med. 2004; 350:2129-2139.

4. Paez JG, Janne PA, Lee JC, Tracy S, Greulich H, Gabriel S, Herman P, Kaye FJ, Lindeman N, Boggon TJ, Naoki K, Sasaki H, Fujii Y, et al. EGFR mutations in lung cancer: correlation with clinical response to gefitinib therapy. Science. 2004; 304:1497-1500.

5. Tsao MS, Sakurada A, Cutz JC, Zhu CQ, Kamel-Reid S, Squire J, Lorimer I, Zhang T, Liu N, Daneshmand M, Marrano P, da Cunha Santos G, Lagarde A, et al. Erlotinib in lung cancer - molecular and clinical predictors of outcome. N Engl J Med. 2005; 353:133-144.

6. Li D, Ambrogio L, Shimamura T, Kubo S, Takahashi M, Chirieac LR, Padera RF, Shapiro GI, Baum A, Himmelsbach F, Rettig WJ, Meyerson M, Solca F, et al. BIBW2992, an irreversible EGFR/HER2 inhibitor highly effective in preclinical lung cancer models. Oncogene. 2008; 27:4702-4711.

7. Godin-Heymann N, Bryant I, Rivera MN, Ulkus L, Bell DW, Riese DJ, 2nd, Settleman J, Haber DA. Oncogenic activity of epidermal growth factor receptor kinase mutant alleles is enhanced by the T790M drug resistance mutation. Cancer Res. 2007; 67:7319-7326.

8. Mulloy R, Ferrand A, Kim Y, Sordella R, Bell DW, Haber DA, Anderson KS, Settleman J. Epidermal growth factor receptor mutants from human lung cancers exhibit enhanced catalytic activity and increased sensitivity to gefitinib. Cancer Res. 2007; 67:2325-2330.

9. Yun CH, Mengwasser KE, Toms AV, Woo MS, Greulich H, Wong KK, Meyerson M, Eck MJ. The T790M mutation in EGFR kinase causes drug resistance by increasing the affinity for ATP. Proc Natl Acad Sci U S A. 2008; 105:2070-2075.

10. Chen LY, Molina-Vila MA, Ruan SY, Su KY, Liao WY, Yu KL, Ho CC, Shih JY, Yu CJ, Yang JC, Rosell R, Yang PC. Coexistence of EGFR T790M mutation and common activating mutations in pretreatment non-small cell lung cancer: A systematic review and meta-analysis. Lung Cancer. 2016; 94:46-53.

11. Sharma SV, Bell DW, Settleman J, Haber DA. Epidermal growth factor receptor mutations in lung cancer. Nat Rev Cancer. 2007; 7:169-181.

12. Maemondo $M$, Inoue A, Kobayashi K, Sugawara S, Oizumi S, Isobe H, Gemma A, Harada M, Yoshizawa H, Kinoshita I, Fujita Y, Okinaga S, Hirano H, et al. Gefitinib or chemotherapy for non-small-cell lung cancer with mutated EGFR. N Engl J Med. 2010; 362:2380-2388.

13. Mitsudomi T, Morita S, Yatabe Y, Negoro S, Okamoto I, Tsurutani J, Seto T, Satouchi M, Tada H, Hirashima T, Asami K, Katakami N, Takada M, et al. Gefitinib versus cisplatin plus docetaxel in patients with non-small-cell lung cancer harbouring mutations of the epidermal growth factor receptor (WJTOG3405): an open label, randomised phase 3 trial. Lancet Oncol. 2010; 11:121-128. 
14. Mitsudomi T, Morita S, Yatabe Y, Negoro S, Okamoto I, Seto T, Satouchi M, Tada H, Hirashima T, Asami K, Katakami N, Takada M, Yoshioka H, et al. Updated overall survival results of WJTOG 3405, a randomized phase III trial comparing gefitinib $(\mathrm{G})$ with cisplatin plus docetaxel (CD) as the first-line treatment for patients with non-small cell lung cancer harboring mutations of the epidermal growth factor receptor (EGFR). J Clin Oncol. 2012; 30:abstr 7521.

15. Mok TS, Wu YL, Thongprasert S, Yang CH, Chu DT, Saijo N, Sunpaweravong P, Han B, Margono B, Ichinose Y, Nishiwaki Y, Ohe Y, Yang JJ, et al. Gefitinib or carboplatinpaclitaxel in pulmonary adenocarcinoma. N Engl J Med. 2009; 361:947-957.

16. Rosell R, Carcereny E, Gervais R, Vergnenegre A, Massuti B, Felip E, Palmero R, Garcia-Gomez R, Pallares C, Sanchez JM, Porta R, Cobo M, Garrido P, et al. Erlotinib versus standard chemotherapy as first-line treatment for European patients with advanced EGFR mutation-positive non-small-cell lung cancer (EURTAC): a multicentre, open-label, randomised phase 3 trial. Lancet Oncol. 2012; 13:239-246.

17. Sequist LV, Yang JC, Yamamoto N, O'Byrne K, Hirsh V, Mok T, Geater SL, Orlov S, Tsai CM, Boyer M, Su WC, Bennouna J, Kato T, et al. Phase III study of afatinib or cisplatin plus pemetrexed in patients with metastatic lung adenocarcinoma with EGFR mutations. J Clin Oncol. 2013; 31:3327-3334.

18. Wu YL, Zhou C, Hu CP, Feng J, Lu S, Huang Y, Li W, Hou M, Shi JH, Lee KY, Xu CR, Massey D, Kim M, et al. Afatinib versus cisplatin plus gemcitabine for first-line treatment of Asian patients with advanced non-small-cell lung cancer harbouring EGFR mutations (LUX-Lung 6): an open-label, randomised phase 3 trial. Lancet Oncol. 2014; 15:213-222.

19. Wu YL, Zhou C, Liam CK, Wu G, Liu X, Zhong Z, Lu S, Cheng Y, Han B, Chen L, Huang C, Qin S, Zhu Y, et al. First-line erlotinib versus gemcitabine/cisplatin in patients with advanced EGFR mutation-positive non-small-cell lung cancer: analyses from the phase III, randomized, open-label, ENSURE study. Ann Oncol. 2015; 26:1883-1889.

20. Zhou C, Wu YL, Chen G, Feng J, Liu XQ, Wang C, Zhang S, Wang J, Zhou S, Ren S, Lu S, Zhang L, Hu C, et al. Erlotinib versus chemotherapy as first-line treatment for patients with advanced EGFR mutation-positive nonsmall-cell lung cancer (OPTIMAL, CTONG-0802): a multicentre, open-label, randomised, phase 3 study. Lancet Oncol. 2011; 12:735-742.

21. Zhou $\mathrm{C}, \mathrm{Wu}$ YL, Chen G, Feng J, Liu XQ, Wang C, Zhang S, Wang J, Zhou S, Ren S, Lu S, Zhang L, Hu C, et al. Final overall survival results from a randomised, phase III study of erlotinib versus chemotherapy as first-line treatment of EGFR mutation-positive advanced non-smallcell lung cancer (OPTIMAL, CTONG-0802). Ann Oncol. 2015; 26:1877-1883.

22. National Comprehensive Cancer Network (NCCN). NCCN clinical practice guidelines in oncology: non-small-cell lung cancer version 4, 2016. https://www.ncen.org/professionals/ physician_gls/pdf/nscl.pdf (accessed July 8, 2016).

23. Park K, Tan EH, O’Byrne K, Zhang L, Boyer M, Mok T, Hirsh V, Yang JC, Lee KH, Lu S, Shi Y, Kim SW, Laskin J, et al. Afatinib versus gefitinib as first-line treatment of patients with EGFR mutation-positive non-small-cell lung cancer (LUX-Lung 7): a phase 2B, open-label, randomised controlled trial. Lancet Oncol. 2016; 17:577-589.

24. Gao G, Ren S, Li A, Xu J, Xu Q, Su C, Guo J, Deng Q, Zhou C. Epidermal growth factor receptor-tyrosine kinase inhibitor therapy is effective as first-line treatment of advanced non-small-cell lung cancer with mutated EGFR: A meta-analysis from six phase III randomized controlled trials. Int J Cancer. 2012; 131:E822-829.

25. Urata Y, Katakami N, Morita S, Kaji R, Yoshioka H, Seto T, Satouchi M, Iwamoto Y, Kanehara M, Fujimoto D, Ikeda N, Murakami H, Daga H, et al. Randomized Phase III Study Comparing Gefitinib With Erlotinib in Patients With Previously Treated Advanced Lung Adenocarcinoma: WJOG 5108L. J Clin Oncol. 2016.

26. Yoshida T, Yamada K, Azuma K, Kawahara A, Abe H, Hattori S, Yamashita F, Zaizen Y, Kage M, Hoshino T. Comparison of adverse events and efficacy between gefitinib and erlotinib in patients with non-small-cell lung cancer: a retrospective analysis. Med Oncol. 2013; 30:349.

27. Engelman JA, Zejnullahu K, Mitsudomi T, Song Y, Hyland C, Park JO, Lindeman N, Gale CM, Zhao X, Christensen J, Kosaka T, Holmes AJ, Rogers AM, et al. MET amplification leads to gefitinib resistance in lung cancer by activating ERBB3 signaling. Science. 2007; 316:1039-1043.

28. Katakami N, Atagi S, Goto K, Hida T, Horai T, Inoue A, Ichinose Y, Koboyashi K, Takeda K, Kiura K, Nishio K, Seki Y, Ebisawa R, et al. LUX-Lung 4: a phase II trial of afatinib in patients with advanced non-small-cell lung cancer who progressed during prior treatment with erlotinib, gefitinib, or both. J Clin Oncol. 2013; 31:3335-3341.

29. Miller VA, Hirsh V, Cadranel J, Chen YM, Park K, Kim SW, Zhou C, Su WC, Wang M, Sun Y, Heo DS, Crino L, Tan EH, et al. Afatinib versus placebo for patients with advanced, metastatic non-small-cell lung cancer after failure of erlotinib, gefitinib, or both, and one or two lines of chemotherapy (LUX-Lung 1): a phase $2 b / 3$ randomised trial. Lancet Oncol. 2012; 13:528-538.

30. Schuler M, Yang JC, Park K, Kim JH, Bennouna J, Chen YM, Chouaid C, De Marinis F, Feng JF, Grossi F, Kim DW, Liu X, Lu S, et al. Afatinib beyond progression in patients with non-small-cell lung cancer following chemotherapy, erlotinib/gefitinib and afatinib: phase III randomized LUXLung 5 trial. Ann Oncol. 2016; 27:417-423.

31. Solca F, Dahl G, Zoephel A, Bader G, Sanderson M, Klein C, Kraemer O, Himmelsbach F, Haaksma E, Adolf GR. Target binding properties and cellular activity of afatinib (BIBW 2992), an irreversible ErbB family blocker. J Pharmacol Exp Ther. 2012; 343:342-350. 
32. Yu HA, Arcila ME, Hellmann MD, Kris MG, Ladanyi M, Riely GJ. Poor response to erlotinib in patients with tumors containing baseline EGFR T790M mutations found by routine clinical molecular testing. Ann Oncol. 2014; 25:423-428.

33. Inoue $\mathrm{A}$, Yoshida $\mathrm{K}$, Morita $\mathrm{S}$, Imamura $\mathrm{F}$, Seto $\mathrm{T}$, Okamoto I, Nakagawa K, Yamamoto N, Muto S, Fukuoka M. Characteristics and overall survival of EGFR mutation-positive non-small cell lung cancer treated with EGFR tyrosine kinase inhibitors: a retrospective analysis for 1660 Japanese patients. Jpn J Clin Oncol. 2016; 46:462-467.

34. Inukai $\mathrm{M}$, Toyooka $\mathrm{S}$, Ito $\mathrm{S}$, Asano $\mathrm{H}$, Ichihara $\mathrm{S}$, Soh J, Suehisa H, Ouchida M, Aoe K, Aoe M, Kiura K, Shimizu N, Date H. Presence of epidermal growth factor receptor gene T790M mutation as a minor clone in non-small cell lung cancer. Cancer Res. 2006; 66:7854-7858.

35. Kris MG, Oxnard GR, Johnson BE, Berry LD, Chen H, Kwiatkowski DJ, Iafrate AJ, Wistuba II, Franklin WA, Aisner D, Sequist LV, Khuri FR, Garon EB, et al. Incidence, characteristics, and survival of patients with EGFR-mutant lung cancers with EGFR T790M at diagnosis identified in the lung cancer mutation consortium (LCMC). J Clin Oncol. 2013; 31:abstr 8085.

36. Li H, Hu H, Wang R, Pan Y, Wang L, Li Y, Zhang Y, Ye T, Zhang Y, Li B, Shen L, Sun Y, Chen H. Primary concomitant EGFR T790M mutation predicted worse prognosis in non-small cell lung cancer patients. Onco Targets Ther. 2014; 7:513-524.

37. Sequist LV, Martins RG, Spigel D, Grunberg SM, Spira A, Janne PA, Joshi VA, McCollum D, Evans TL, Muzikansky A, Kuhlmann GL, Han M, Goldberg JS, et al. First-line gefitinib in patients with advanced non-small-cell lung cancer harboring somatic EGFR mutations. J Clin Oncol. 2008; 26:2442-2449.

38. Stahel RA, Dafni U, Gautschi O, Felip E, CurioniFontecedro A, Peters S, Massutí B, Cardenal F, Aix SP, Früh M, Pless M, Popat S, Kotsakis A, et al. Abstracts from the European Cancer Congress 20153BA A phase II trial of erlotinib (E) and bevacizumab (B) in patients with advanced non-small-cell lung cancer (NSCLC) with activating epidermal growth factor receptor (EGFR) mutations with and without T790M mutation. The Spanish Lung Cancer Group (SLCG) and the European Thoracic Oncology Platform (ETOP) BELIEF trial. Euro J Cancer. 2015; 51:abstr S711-S712.

39. Wu JY, Yu CJ, Chang YC, Yang CH, Shih JY, Yang PC. Effectiveness of tyrosine kinase inhibitors on "uncommon" epidermal growth factor receptor mutations of unknown clinical significance in non-small cell lung cancer. Clin Cancer Res. 2011; 17:3812-3821.

40. Ramalingam SS, Janne PA, Mok T, O'Byrne K, Boyer MJ, Von Pawel J, Pluzanski A, Shtivelband M, Docampo LI, Bennouna J, Zhang H, Liang JQ, Doherty JP, et al. Dacomitinib versus erlotinib in patients with advancedstage, previously treated non-small-cell lung cancer
(ARCHER 1009): a randomised, double-blind, phase 3 trial. Lancet Oncol. 2014; 15:1369-1378.

41. Yang JC, Sequist LV, Geater SL, Tsai CM, Mok TS, Schuler M, Yamamoto N, Yu CJ, Ou SH, Zhou C, Massey D, Zazulina V, Wu YL. Clinical activity of afatinib in patients with advanced non-small-cell lung cancer harbouring uncommon EGFR mutations: a combined posthoc analysis of LUX-Lung 2, LUX-Lung 3, and LUX-Lung 6. Lancet Oncol. 2015; 16:830-838.

42. Douillard JY, Ostoros G, Cobo M, Ciuleanu T, McCormack R, Webster A, Milenkova T. First-line gefitinib in Caucasian EGFR mutation-positive NSCLC patients: a phase-IV, open-label, single-arm study. Br J Cancer. 2014; 110:55-62.

43. Hayashibara K, Satoh H, Shinohara Y, Inagaki M, Kaburagi T, Hashimoto T, Kurishima K, Ishikawa H, Ichimura $H$, Nawa T, Funayama Y, Matsumura T, Kagohashi K, et al. A population-based study of gefitinib in patients with non-small cell lung cancer. Med Oncol. 2009; 26:222-227.

44. Chen YM, Lai CH, Chang HC, Chao TY, Tseng CC, Fang WF, Wang CC, Chung YH, Wang YH, Su MC, Huang KT, Chen HC, Lin MC. The impact of clinical parameters on progression-free survival of non-small cell lung cancer patients harboring EGFR-mutations receiving first-line EGFR-tyrosine kinase inhibitors. Lung Cancer. 2016; 93:47-54.

45. Lin JJ, Cardarella S, Lydon CA, Dahlberg SE, Jackman DM, Janne PA, Johnson BE. Five-Year Survival in EGFR-Mutant Metastatic Lung Adenocarcinoma Treated with EGFRTKIs. J Thorac Oncol. 2016; 11:556-565.

46. Faber AC, Corcoran RB, Ebi H, Sequist LV, Waltman BA, Chung E, Incio J, Digumarthy SR, Pollack SF, Song Y, Muzikansky A, Lifshits E, Roberge S, et al. BIM expression in treatment-naive cancers predicts responsiveness to kinase inhibitors. Cancer Discov. 2011; 1:352-365.

47. Isobe K, Hata Y, Tochigi N, Kaburaki K, Kobayashi H, Makino T, Otsuka H, Sato F, Ishida F, Kikuchi N, Hirota N, Sato K, Sano G, et al. Clinical significance of BIM deletion polymorphism in non-small-cell lung cancer with epidermal growth factor receptor mutation. J Thorac Oncol. 2014; 9:483-487.

48. Zhao M, Zhang Y, Cai W, Li J, Zhou F, Cheng N, Ren R, Zhao C, Li X, Ren S, Zhou C, Hirsch FR. The Bim deletion polymorphism clinical profile and its relation with tyrosine kinase inhibitor resistance in Chinese patients with nonsmall cell lung cancer. Cancer. 2014; 120:2299-2307.

49. Lee JK, Shin JY, Kim S, Lee S, Park C, Kim JY, Koh Y, Keam B, Min HS, Kim TM, Jeon YK, Kim DW, Chung DH, et al. Primary resistance to epidermal growth factor receptor (EGFR) tyrosine kinase inhibitors (TKIs) in patients with non-small-cell lung cancer harboring TKI-sensitive EGFR mutations: an exploratory study. Ann Oncol. 2013; 24:2080-2087.

50. Haspinger ER, Agustoni F, Torri V, Gelsomino F, Platania M, Zilembo N, Gallucci R, Garassino MC, Cinquini M. Is 
there evidence for different effects among EGFR-TKIs? Systematic review and meta-analysis of EGFR tyrosine kinase inhibitors (TKIs) versus chemotherapy as first-line treatment for patients harboring EGFR mutations. Crit Rev Oncol Hematol. 2015; 94:213-227.

51. Didelot A, Le Corre D, Luscan A, Cazes A, Pallier K, Emile JF, Laurent-Puig P, Blons H. Competitive allele specific TaqMan PCR for KRAS, BRAF and EGFR mutation detection in clinical formalin fixed paraffin embedded samples. Exp Mol Pathol. 2012; 92:275-280.

52. Shaozhang Z, Ming Z, Haiyan P, Aiping Z, Qitao Y, Xiangqun S. Comparison of ARMS and direct sequencing for detection of EGFR mutation and prediction of EGFRTKI efficacy between surgery and biopsy tumor tissues in NSCLC patients. Med Oncol. 2014; 31:926.

53. Nishino M, Jackman DM, Hatabu H, Yeap BY, Cioffredi LA, Yap JT, Janne PA, Johnson BE, Van den Abbeele AD. New Response Evaluation Criteria in Solid Tumors (RECIST) guidelines for advanced non-small cell lung cancer: comparison with original RECIST and impact on assessment of tumor response to targeted therapy. AJR Am J Roentgenol. 2010; 195:W221-228. 